\title{
Effect of Ad libitum and Restricted Milk Feeding on Growth Performance of Holstein Calves
}

\author{
M. A. Khan*, H. J. Lee*, W. S. Lee*, K. S. Ki*, H. S. Kim*, B. S. Ahn*, S. B. Park*,
}

\author{
Z. S. Hong** and Y. J. Choi**
}

National Livestock Research Institute, R.D.A.*, School of Agricultural Biotechnology, Seoul National University**

제한 및 무제한 포유방법이 홀스타인 송아지의 성장능력에 미치는 영향

M. A. Khan* - 이현준* • 이왕식* - 기광석* • 김현섭* • 안병석* • 박수봉* · 홍중산** - 최윤재**

농촌진흥청 축산연구소*, 서울대학교 농업생명과학대학 농생명공학부**

요 약

본 연구는 2 개월간의 포유기간 동안 홀스타인 젖소 송아지를 무제한 포유방법을 사용하여 무제한 포유시 송아지의 최대 우유섭취량과 급여회수를 조사하고 관행의 제한 포유방법(10\%/live weight, kg) 과 송아지의 성장능력, 설사발생, 사료건물 섭취량 등에 대한 영향을 비교하였다. 신생 홀스타인 젖소 20 두를 공시하여 체중의 $10 \%$ 로 제한 포유구(conventional)와 무제한포유구(4 6회/일)로 각각 10 두씩 구분하여 초유는 출생 후 3 일 동안 급여하고 이후 60 일령에 이유할 때까지 5 일 간격의 체중조사 값 에 따라 관행방법과 무제한 포유방법을 각각 개체별로 실시하였다. 무제한 포유송아지의 출생당일에 생체중의 $13.49 \%$ 에서 30 일령에는 $23.51 \%$ 로 섭취량이 최대값을 나타났다가 이후 감소하는 것으로 나 타났으며, 포유기간 전체 평균 우유섭취량은 관행포유구는 $4.3 \mathrm{~kg}$, 무제한포유구는 $9.8 \mathrm{~kg}$ 으로 나타났 다 $(\mathrm{p}<0.05)$. 어린송아지사료(젖 떼기용 사료)와 혼합목초건초 섭취량은 시험송아지 모두가 일령 증가에 따라 증가하여 40 일령까지는 시험구간에 현저한 차이는 나타나지 않았고 시험 전기간 동안의 관행포 유구의 송아지가 건물 섭취량, 조단백 섭취량 및 가소화영양소총량(TDN) 섭취량에서 무제한 포유구 의 것보다 각각 $18.4 \%, 20.0 \%$ 및 $18.9 \%$ 많이 섭취한 것으로 나타났다(p<0.05). 1 개월령과 2 개월령 및 포유기간 전기간 동안의 송아지의 체중 증가에 있어서 무제한 포유구 송아지의 것이 관행구 송아지 의 것에 비해 각각 $49 \%, 18.4 \%, 26 \%$ 의 증체효과를 나타냈는데, 20 일령까지는 시험구간의 체중차이가 뚜렷하지 않았지만 30일령이후 90일령(이유 후 30일령)까지는 무제한 구의 송아지의 체중이 유의하게 높은 것으로 나타났다 $(\mathrm{p}<0.05)$. 그리고 120 일령 이후 180 일령까지 체중변화를 살펴보았을 때, 시험구 간 체중은 비슷해지는 것을 알 수 있었다. 사료효율은 무제한 포유구의 것보다 관행구의 것이 더 높 은 것으로 나타났으며 $(\mathrm{p}<0.05)$, 시험 전기간 동안 감기, 발열, 설사 등의 질병은 모든 시험구에서 나타 나지 않았다. 본 시험을 통해 우리는 무제한 포유방법은 이유 전 송아지의 빠른 성장과 건강유지에 도움이 됨과 이 영향은 최소한 90 일령까지 지속된다는 결론을 얻었다.

(Key words : Holstein calf, Weaning, Colostrum, Milk feeding)

\section{I . INTRODUCTION}

An efficient calf feeding system is crucial to have good dairy replacement stock that decides the future income and sustainability of a dairy enterprise. The manner in which the calves are fed milk or milk replacer after separation from their dams have shown its significant effects on their behavior, health, performance and welfare. Commonly the dairy calves are fed restricted

Corresponding author : Hyun June Lee, Dairy Science Division, National Livestock Research Institute, Rural development Administration, Cheonan, 330-801, Korea.

Tel : +82 41-580-3395 Fax : +82 41-580-3419, E-mail : dadim922@rda.go.kr 
quantity (10\% of calf's body weight) of colostrum and then milk after separation from their mothers in two meals daily through bucket (Thickett et al., 1983). This method adds to veterinary and hygienic reasons for penning them individually, because they take less than 1 minute to consume each of their meals, they do very little sucking and they then suck other calves and objects if available (Rushen and de Passillé, 1995). Milk feeding through nipple has been proved better than bucket because this method allows calves to express their natural sucking behavior (Hammell et al., 1988), may also reduces cross suckling (Flower and Weary, 2001) and perhaps improves digestion (Jasper and Weary, 2002). Increasing public concern over individual housing and feeding methods (Rushen and de Passillé, 1995) has led to investigation of ways to improve calf feeding methods.

A calf left with its dam in a cow-calf system usually suckle about 8 to 10 times a day and consume more milk (Albright and Arave, 1997) than restricted fed calves. Because of the increased frequency of suckling and total intake of milk, calves kept with the cows gain more weight at several times than conventionally reared calves (Flower and Weary, 2001; Metz, 1987). However, because of a number of reasons including management, time, labor, and expense the dairy farmers were unwilling to delay the separation of calves from the cows. Based on the above observations, Jasper and Weary (2002) fed ad libitum milk to dairy calves for the first four weeks and reported that calves fed ad libitum consumed 89\% more milk and gained $63 \%$ more body weight at weaning than calves fed conventionally. However, the scientific literature on the effect of ad libitum milk feeding of Holstein calves on their performance and health is scarce. Only few other studies have been reported that calves were fed ad libitum milk through bucket, or automated system for the first three or four weeks of their life (Hammon et al., 2002; Appleby et al., 2001).

This study was conducted to estimate the maximum amount and time of milk consumption by Holstein calves during two months of preweaning period and to compare ad libitum milk feeding with conventional system for their effects on dry feed consumption, nutrient intake, growth performance and occurrence of diarrhea.

\section{MATERIALS AND METHODS}

\section{Animal and experimental methods}

This study was carried out at the National Livestock Research Institute, South Korea. Holstein calves $(\mathrm{n}=20)$ born from November to December, 2004 were separated from their mothers within $3 \mathrm{~h}$ of birth, weighed, and moved into individual pens. Calves were alternatively fed colostrum $10 \%$ of their body weight or ad libitum for the first three days (d) and then assigned to conventional ( $n=10$; calves were fed milk $10 \%$ of their body weight from birth to weaning at d 60 of their age) or ad libitum milk feeding ( $\mathrm{n}=10$; calves were fed ad libitum milk from birth to weaning at d 60 of their age). All calves were fed whole milk stored in a milk tank at $4-6^{\circ} \mathrm{C}$ after milking using a milking machine(DeLaval Tandem Stall, Sweden). The milk temperature was raised to $36-37^{\circ} \mathrm{C}$ before feeding to calves. Colostrum and milk samples were analyzed with a milk composition analyzer(Lactoscope ${ }^{\circledR}$ MK2, Delta Instruments, Drachten, The Netherlands). Chemical composition of colostrum and milk is given in Table 1.

All calves were housed in individual pens interspersed evenly throughout the calf barn. Pens had solid iron rod sides, with openings in the front and rear to allow calves free access to calf starter and chopped mixed grass hay (43\% orchard grass $+43 \%$ tall fescue $+14 \%$ white clover). Dry matter (DM), crude protein (CP), ash, phosphorus 
Table 1. Chemical composition (mean \pm standard deviation) of colostrum and milk

\begin{tabular}{|c|c|c|c|c|}
\hline \multirow{2}{*}{ Composition (\%) } & \multicolumn{3}{|c|}{ Colostrum $^{1)}$} & \multirow{2}{*}{ Milk $^{2)}$} \\
\hline & Day -1 & Day -2 & Day -3 & \\
\hline Fat & $5.98 \pm 0.14$ & $4.30 \pm 0.10$ & $3.95 \pm 0.05$ & $3.80 \pm 0.11$ \\
\hline Protein & $17.40 \pm 0.30$ & $8.94 \pm 0.10$ & $5.40 \pm 0.04$ & $3.39 \pm 0.06$ \\
\hline Lactose & $3.81 \pm 0.03$ & $3.68 \pm 0.02$ & $4.30 \pm 0.02$ & $4.71 \pm 0.04$ \\
\hline Total solids & $27.80 \pm 0.40$ & $17.10 \pm 0.20$ & $14.30 \pm 0.10$ & $12.86 \pm 0.14$ \\
\hline $\mathrm{FFA}^{3)}(\mathrm{meq} / \mathrm{dl})$ & $1.60 \pm 0.05$ & $0.96 \pm 0.05$ & $0.85 \pm 0.04$ & $0.70 \pm 0.03$ \\
\hline Citrate (mg/L) & $0.06 \pm 0.01$ & $0.16 \pm 0.01$ & $0.15 \pm 0.01$ & $0.17 \pm 0.01$ \\
\hline $\mathrm{MUN}^{4)}$ (mg/dl) & $\mathrm{ND}^{5)}$ & $\mathrm{ND}^{5)}$ & $\mathrm{ND}^{5)}$ & $13.34 \pm 4.30$ \\
\hline Ca (mg/dl) & \pm 0.08 & \pm 0.05 & \pm 0.05 & $121 \pm 0.03$ \\
\hline P (mg/dl) & \pm 0.06 & \pm 0.04 & \pm 0.04 & $78 \pm 0.05$ \\
\hline
\end{tabular}

1) Each day a.m. and p.m. colostrum samples were composited for analysis $(\mathrm{n}=20)$.

2) Milk storage tank samples $(n=30) \quad$ 3) Free fatty acids

4) Milk urea nitrogen ${ }^{5)}$ No detected.

and calcium in starter and hay were analyzed by procedures of AOAC (1999). Neutral detergent fiber and acid detergent fiber in starter and hay were analyzed by procedure of Van Soest et al. (1991). Total digestible nutrients (TDN) in both calf starter and hay were estimated using an equation of NRC (2001). Chemical composition of calf starter and hay is given in Table 2 . Calves were provided free access to water from a bowl drinker in each pen. These calves were raised as replacement heifers for Dairy Science Division herd at National Livestock Research Institute, South Korea.

All calves were fed milk using mobile plastic bottles (2.5 L capacity) fitted with soft rubber nipples (Fullwood Ltd., Norfolk, UK). A steel bottle stand was attached to iron rod at the front side of individual pen at $70 \mathrm{~cm}$ above the floor. At each feeding bottle containing milk was fitted into that stand and after feeding the bottle was removed from the stand. The bottles were washed using a washing detergent(DeLaval Alodine de tergent, Sweden ; its acid content prevents buildup of milk-stone and iodine provides efficient bactericidal effect) after each feeding, dried and kept in the bottle cabinet up side down to prevent from any contamination until next feeding.

Conventionally fed calves were fed milk twice

Table 2. Chemical composition (mean \pm standard deviation) of calf starter, and mixed grass hay on dry matter basis

\begin{tabular}{lcc}
\hline Parameters (\%) & Calf starter & $\begin{array}{c}\text { Mixed grass } \\
\text { hay }\end{array}$ \\
\hline \hline Dry matter & $88.90 \pm 0.21$ & $91.01 \pm 0.40$ \\
Crude protein & $22.45 \pm 0.33$ & $13.71 \pm 0.61$ \\
TDN $^{2)}$ & $72.30 \pm 1.20$ & $54.10 \pm 1.04$ \\
Neutral detergent fiber & $12.10 \pm 0.62$ & $65.40 \pm 2.62$ \\
Acid detergent fiber & $5.97 \pm 0.52$ & $36.50 \pm 2.10$ \\
Ash & $3.70 \pm 0.15$ & $6.73 \pm 0.11$ \\
Ca & $0.17 \pm 0.02$ & $0.67 \pm 0.10$ \\
Phosphorus & $0.51 \pm 0.03$ & $0.26 \pm 0.05$ \\
\hline
\end{tabular}

1) Mixed grass hay $=43 \%$ Orchard grass $+43 \%$ tall fescue $+14 \%$ white clover (DM basis)

2) TDN (Total digestible nutrients) was calculated using an equation of NRC (2001). 
daily (0600 and $1700 \mathrm{~h}$ ) in such a way that milk weight totaled $10 \%$ of the calf's body weight, distributed evenly across the two feedings. In ad libitum milk feeding the milk was provided not more than 2 liters in one feeding. The calves were fed milk after every two hours of interval unless they refused $10 \%$ milk in a day. Calves in both conventional and ad libitum groups were weaned gradually by diluting milk with water between d 56 and 60 . The amount of water increased by $10 \%$ of total volume of milk at each feeding so that on the morning of $d 60$, calves received $100 \%$ water.

Daily milk, starter and hay intake was recorded throughout the experiment. Average birth weight of calves in conventional $(39.80 \pm 2.10)$ and $a d$ libitum $(41.50 \pm 1.41)$ groups were the same. Calves were weighed after every 10 days during preweaning (milk weight was adjusted individually according to each calf's weight), at day after weaning (d 60), and at d 90, 120, 150 and 180 post-weaning.

Fecal scoring for the determination of fecal fluidity, consistency, odor, and days scoured was conducted daily at morning time (07:00) using the procedure of Larson et al. (1977). Fecal coring was as follows: for fecal fluidity, $1=$ normal, 2 = soft, 3 = runny, and 4 = watery; for fecal consistency, 1 = normal, 2 = foamy, 3 = mucousy, 4 = sticky, and 5 = constipated; for fecal odor, 1 = normal, 2 = slightly offensive, or 3 = highly offensive. A scour day was recorded if fecal fluidity $=3$ or 4 , fecal consistency $=3$, and fecal odor $=2$ or 3 .

Average daily milk, starter, mixed grass hay, DM (starter plus hay), TDN and CP intakes weight gain, total DM intake (milk, starter and hay) and feed efficiency (Feed efficiency $=\mathrm{kg}$ of BW gain $/ \mathrm{kg}$ of DM intake) were calculated for each of the three phases of the experiment: the first month (d 1 to 30), the second month (d 31 to 60 ), and birth to weaning (d 1 to 60 ).

\section{Statistical analysis}

Values of milk intake, feed consumption (starter and hay), growth performance data, were expressed as means \pm standard error of the means. Differences in feed and nutrient intake were evaluated by means of Wilcoxon's two-sample test (SAS, 1994) because of the lack of normal data distribution. Group differences of growth performance data were evaluated by Student's t-test (SAS, 1994).

\section{RESULTS}

Mean daily milk intake was increased in conventionally fed calves steadily from $3.68 \mathrm{~kg}$ at day first to $5.91 \mathrm{~kg}$ at day 55 of their age (Figure 1). In ad libitum fed calves mean daily milk intake was increased during the first week however; a decreasing trend was observed in the second week of life thereafter it increased and reached to maximum value of $13.56 \mathrm{~kg}$ at d 55 of their age (Figure 1). Milk intake as percent of body weight was increased in ad libitum fed calves from $13.49 \%$ at day 1 to $23.51 \%$ at $\mathrm{d} 30$ of their age thereafter it was gradually reduced

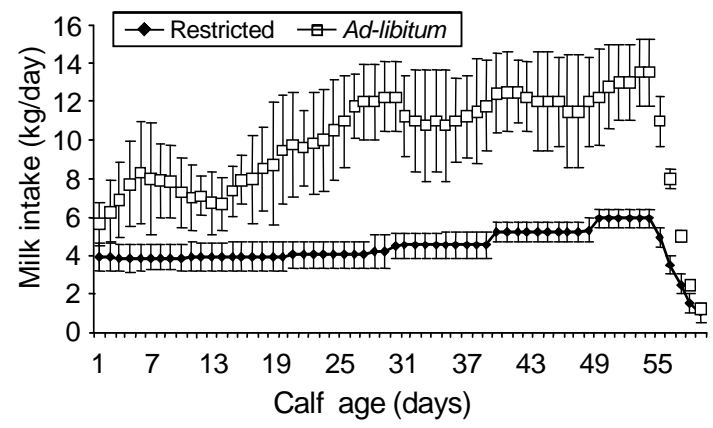

Calves in both restricted and ad-libitum groups were weaned gradually by diluting milk with water between d 56 and 60 .

Fig. 1. Mean( \pm SE) daily milk intake by Holstein calves fed either restricted $(n=10 ; 10 \%$ of calves body weight) or ad-libitum ( $\mathrm{n}=$ 10) milk amounts. 


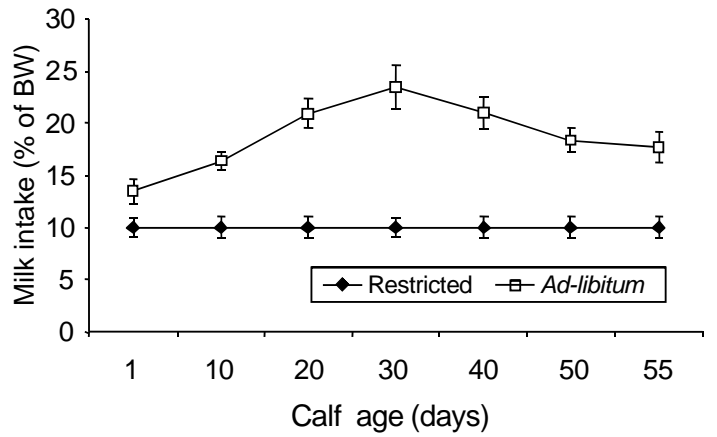

Fig. 2. Mean ( \pm SE) milk intake as percent of body weight (BW) in Holstein calves fed either restricted $(n=10)$ or ad libitum $(n=10)$ quantity of milk from birth to weaning (60 d of age).

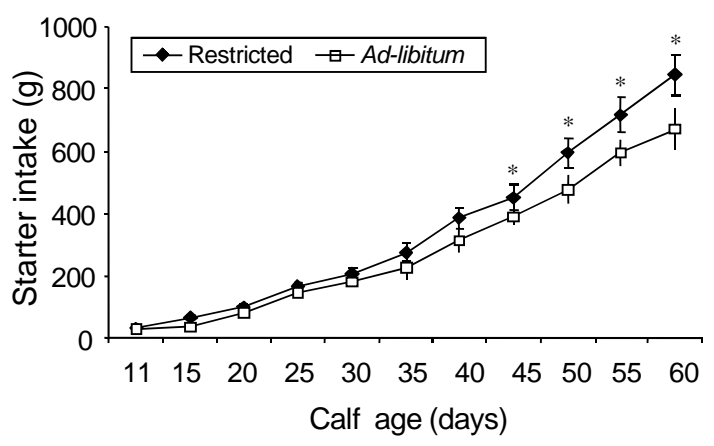

* Means are significantly different $(\mathrm{P}<0.05)$ between groups.

Fig. 3. Mean ( \pm SE) starter dry matter intake by Holstein calves fed either restricted $(n=10$; $10 \%$ of calves body weight) or ad-libitum $(n=10)$ milk amounts from birth to weaning (60 d of age).

and at $\mathrm{d} 55$ the calves consumed milk at the rate of $17.7 \%$ of their body weight (Figure 2). The ad libitum fed calves consumed 2.25, and 2.30 times more milk than conventionally fed calves during the first and second months of their age. From birth to weaning, mean daily milk intake was $9.8 \mathrm{~kg}$ for ad libitum fed group compared with $4.3 \mathrm{~kg}$ for restricted fed calves that was 2.28 times higher in the former (Table 4).

Daily starter and mixed grass hay intake was gradually increased in both groups with the advancing age however, the group difference was noted non-significant up to $40 \mathrm{~d}$ of calves age. Conventionally fed calves ate significantly $(P<0.05)$ higher amount of starter (Figure 3) and mixed

Table 3. Mean daily milk, starter, mixed grass hay and nutrients intake by Holstein calves fed either restricted $(n=10$; $10 \%$ of calves body weight) or adlibitum $(n=10)$ milk amounts from birth to weaning (60 d of age)

\begin{tabular}{|c|c|c|c|}
\hline \multicolumn{4}{|c|}{ Treatments } \\
\hline Traits & Restricted & Ad-libitum & SE \\
\hline \multicolumn{4}{|l|}{ Milk (kg) } \\
\hline D 1 to 30 & $3.9^{b}$ & $8.8^{\mathrm{a}}$ & 0.47 \\
\hline D 31 to 60 & $4.7^{\mathrm{b}}$ & $10.8^{\mathrm{a}}$ & 0.61 \\
\hline D 1 to 60 & $4.3^{\mathrm{b}}$ & $9.8^{\mathrm{a}}$ & 0.56 \\
\hline \multicolumn{4}{|l|}{ Starter (g) } \\
\hline D 1 to 30 & 113.2 & 93.2 & 13.2 \\
\hline D 31 to 60 & $510.1^{\mathrm{a}}$ & $435.7^{\mathrm{b}}$ & 40.1 \\
\hline D 1 to 60 & $311.6^{\mathrm{a}}$ & $254.4^{\mathrm{b}}$ & 28.7 \\
\hline \multicolumn{4}{|c|}{ Mixed grass hay (g) } \\
\hline D 1 to 30 & 122 & 131.0 & 15.6 \\
\hline D 31 to 60 & $527.6^{\mathrm{a}}$ & $435.7^{\mathrm{b}}$ & 36.4 \\
\hline D 1 to 60 & $324.8^{\mathrm{a}}$ & $283.3^{\mathrm{b}}$ & 31.1 \\
\hline \multicolumn{4}{|c|}{ Dry matter $^{1)}(\mathrm{g})$} \\
\hline D 1 to 30 & 235.2 & 224.2 & 18.1 \\
\hline D 31 to 60 & $1,037.7^{\mathrm{a}}$ & $851.3^{\mathrm{b}}$ & 84.9 \\
\hline D 1 to 60 & $636.4^{\mathrm{a}}$ & $537.7^{\mathrm{b}}$ & 62.2 \\
\hline \multicolumn{4}{|c|}{ Crude protein $^{1)}$ (g) } \\
\hline D 1 to 30 & 42.1 & 38.8 & 3.2 \\
\hline D 31 to 60 & $186.8^{\mathrm{a}}$ & $153.0^{\mathrm{b}}$ & 11.0 \\
\hline D 1 to 60 & $114.4^{\mathrm{a}}$ & $95.9^{\mathrm{b}}$ & 9.9 \\
\hline \multicolumn{4}{|l|}{$\mathrm{TDN}^{2)}(\mathrm{g})$} \\
\hline D 1 to 30 & 147.8 & 138.3 & 10.2 \\
\hline D 31 to 60 & $654.2^{\mathrm{a}}$ & $536.1^{\mathrm{b}}$ & 39.4 \\
\hline D 1 to 60 & $401.0^{\mathrm{a}}$ & $337.2^{\mathrm{b}}$ & 27.1 \\
\hline
\end{tabular}

1) Average nutrients intake of starter and mixed grass hay (without milk nutrients)

2) TDN(Total digestible nutrients) was calculated using an equation of NRC (2001).

${ }^{\text {ab }}$ Means in the same row with different superscripts $\operatorname{differ}(\mathrm{P}<0.05)$. 
Table 4. Body weight, body weight gain, total dry matter intake, and feed efficiency in Holstein calves fed either restricted ( $n=10 ; 10 \%$ of calves body weight) or ad-libitum $(\mathrm{n}=10)$ milk amounts from birth to weaning (60 d of age)

\begin{tabular}{cccc}
\hline \multirow{2}{*}{ Traits } & \multicolumn{2}{c}{ Treatments } & \multirow{2}{*}{ SE } \\
\cline { 2 - 3 } & Restricted Ad-libitum & \\
\hline \hline Body weight (kg) & & & \\
D 1 & 39.80 & 41.50 & 3.33 \\
D 30 & $46.91^{\mathrm{b}}$ & $52.11^{\mathrm{a}}$ & 4.01 \\
D 60 & $68.50^{\mathrm{b}}$ & $77.65^{\mathrm{a}}$ & 5.53 \\
\hline Body weight gain (kg) & & & \\
D 1 & $7.11^{\mathrm{b}}$ & $10.6^{\mathrm{a}}$ & 0.95 \\
D 30 & $21.60^{\mathrm{b}}$ & $25.55^{\mathrm{a}}$ & 1.42 \\
D 60 & $28.70^{\mathrm{b}}$ & $36.15^{\mathrm{a}}$ & \\
\hline Total DMI ${ }^{1)}(\mathrm{kg})$ & & & \\
D 1 to 30 & $22.33^{\mathrm{b}}$ & $40.23^{\mathrm{a}}$ & 3.21 \\
D 31 to 60 & $49.25^{\mathrm{b}}$ & $67.01^{\mathrm{a}}$ & 4.44 \\
D 1 to 60 & $71.58^{\mathrm{b}}$ & $107.24^{\mathrm{a}}$ & 7.58 \\
\hline Feed efficiency $^{2)}$ & & & \\
D 1 to 30 & $0.32^{\mathrm{a}}$ & $0.27^{\mathrm{b}}$ & 0.02 \\
D 31 to 60 & $0.43^{\mathrm{a}}$ & $0.38^{\mathrm{b}}$ & 0.03 \\
D 1 to 60 & $0.40^{\mathrm{a}}$ & $0.34^{\mathrm{b}}$ & 0.02 \\
\hline
\end{tabular}

1) DMI = sum of milk, starter and mixed grass hay dry matter during given periods

2) Feed efficiency $=\mathrm{kg}$ of $\mathrm{BW}$ gain $/ \mathrm{kg}$ of $\mathrm{DM}$ intake

ab Means in the same row with different superscripts differ $(\mathrm{P}<0.05)$.

grass hay (Figure 4) at 45, 50, 55 and $60 \mathrm{~d}$ of their age than ad libitum milk fed calves. Starter and mixed grass hay intakes were non-significant between groups for first month, however, significantly $(P<0.05)$ higher intake of starter and mixed grass hay was observed in conventionally fed calves than ad libitum milk fed calves for second month of their age (Table 3). From birth to weaning ad libitum fed calves consumed 23 and $15 \%$ more starter and mixed grass hay than conventional fed calves, respectively.

Daily DM, CP and TDN intakes from starter and hay (dry feed) were numerically higher in

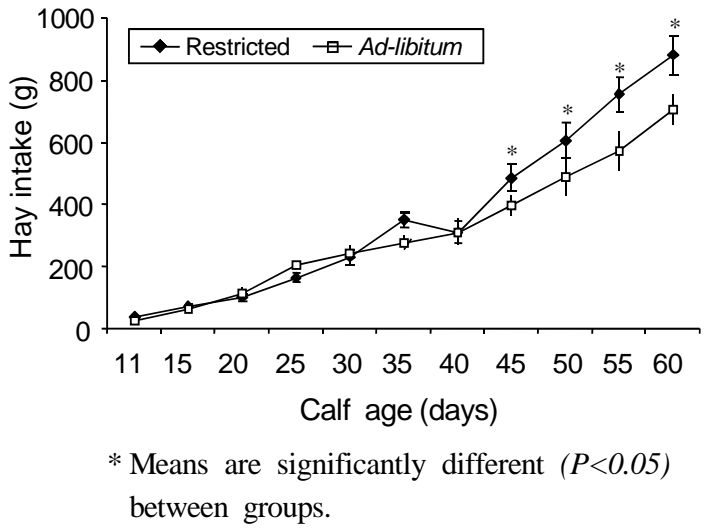

Fig. 4. Mean ( $\pm S E)$ mixed grass hay dry matter intake by Holstein calves fed either restricted $(n=10 ; 10 \%$ of calves body weight) or ad-libitum ( $\mathrm{n}=10)$ milk amounts from birth to weaning (60 d of age).

conventionally fed calves than ad libitum milk fed calves however; the group differences were not significant for the first month of their age (Table 3). Daily DM, CP and TDN intakes from dry feed were significantly $(P<0.05)$ higher for conventionally fed calves than ad libitum milk fed calves for the second month of their age. Overall from birth to weaning conventional fed calves consumed 18.4, 20 and 18.9\% more DM, $\mathrm{CP}$ and TDN than ad libitum milk fed calves, respectively.

Body weight was not significantly different between groups for first $20 \mathrm{~d}$ of calves' age however, it was significantly $(P<0.05)$ higher for ad libitum milk fed calves at d 30, 40, 50, 60 and d 90 of their age (Figure 5). Similar body weights for both conventional and ad libitum milk fed calves were observed for post weaning period at 120, 150 and $180 \mathrm{~d}$ of calves' age. The ad libitum milk fed calves gained 10.6, 25.55 and $36.15 \mathrm{~kg}$ compared with 7.11, 21.60 and $28.7 \mathrm{~kg}$ for conventionally fed calves during the first month, the second month and overall from birth to weaning, respectively. The weight gain was 49, 18.4 and 26\% higher in ad libitum milk fed calves than conventionally fed calves 


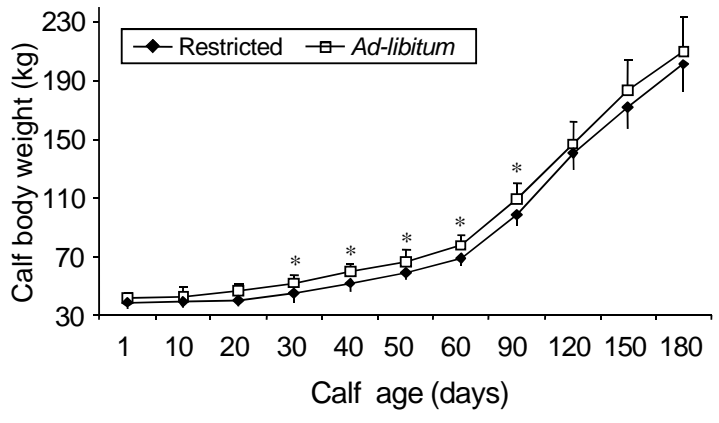

* Means are significantly different $(P<0.05)$ between groups.

Fig. 5. Mean ( \pm SE) pre-weaning and postweaning body weight of Holstein calves fed either restricted $(n=10 ; 10 \%$ of calves body weight) or ad-libitum ( $n=10)$ milk amounts from birth to weaning (60 d of age).

during the first month, the second month and from birth to weaning, respectively.

Feed efficiency ( $\mathrm{kg}$ of body weight gain $/ \mathrm{kg}$ of DM intake) was significantly $(\mathrm{P}<0.05)$ higher for calves fed conventionally than ad libitum milk fed calves during the first month, the second month and from birth to weaning. No sign of diarrhea, fever or cough was observed in calves fed either conventionally or ad libitum milk amount during the experimental period.

\section{DISCUSSION}

Calves fed ad libitum clearly consumed more milk than conventionally fed calves during the first and second month of their age. Similar results have been documented previously by Jasper and Weary (2002), Appleby et al., (2001) and Hammell et al., (1988) when they fed calves ad libitum milk for the first 4 weeks of their age. A polynomial trend in daily milk intake (as percent of body weight) was observed in calves fed ad libitum with maximum milk intake as percent of body weight (23.15\%) between 4 to 5 weeks of their age. This trend specifies that calf can handle much more milk than fed under conventional system without any digestive trouble if managed properly. Appleby et al. (2001) reported that calves consumed an average of approximately 10 $\mathrm{kg}$ of milk per day, spread over 10 meals when fed ad libitum amounts through nipple. Increased daily milk intake with age in ad libitum milk fed calves indicates their increased digestive capacity (de Passillé et al., 1992). However, increase in the consumption of dry feed at 6 weeks of age has probably reduced the milk intake in ad libitum fed calves even though the ad libitum fed calves continued to consume much higher daily milk than conventionally fed calves up to their weaning.

The mean daily starter and mixed grass hay intakes were similar between groups for the first month. Other studies (Jasper and Weary, 2002; Leaver and Yarrow, 1972) have reported similar results when calves were fed ad libitum milk. However, in the second month of their age the ad libitum fed calves consumed significantly less starter and mixed grass hay. Similar to the present results Khalili et al., (1992) reported that calves provided with more milk consumed less calf starter and hay.

Significantly higher intakes of DM, CP and TDN from dry feed by conventionally fed calves during the second month of age were because of the increased intake of starter and mixed grass hay. When calves consumed ad libitum milk, they habitually consumed less dry feed (Fiems et al., 1982; Bøe and Havrevoll, 1993) and this can lead to post-weaning lag in intake (Thickett et al., 1983) and growth (Nocek and Braund, 1986). However, in this study no post weaning lag was observed in growth rather the body weight was higher in ad libitum milk fed calves than conventionally fed calves up to 90 days of age. Jasper and Weary (2002) found no evidence that reduced intake before weaning led to reduced intakes after calves were weaned from milk. The 
effects of increased milk consumption more than compensated for the reduced intake of hay and starter before weaning, such that the calves fed ad libitum gained more weight than the conventionally fed calves before weaning, and maintained that weight advantage until at least for 90 days of age. Significantly higher body weight gain in ad libitum milk fed calves was because of much higher milk intake. Previous studies (Jasper and Weary 2002; Appleby et al., 2001; Riordan and Everett, 1972) have shown that early weight advantages can be maintained far beyond the scope of the increased feeding. They explained that early weight advantage may lower the age at the first calving and reduce the costs of production (Cady and Smith, 1996). Also, unlike older heifers, high growth rates for calves under $90 \mathrm{~kg}$ have no negative effects on mammary development (Sejrsen et al., 2000).

Although the weight gain was higher in ad libitum fed calves however, because of the much higher DM intake, the feed efficiency at the first and second month of age was lower with this group compared to conventionally fed calves. Hammon et al. (2002) also reported the low feed efficiency in ad libitum milk fed calves for first month of age and attributed this to reduced feed utilization and increased maintenance cost in heavier calves.

In present study, no sign of diarrhea was noted in both groups fed either conventionally or ad libitum milk for first or second month of their age. Previous workers (Hammon et al., 2002; Jasper and Weary 2002; Appleby et al., 2001;) reported that incidence of diarrhea was low and did not differ between conventionally and ad libitum milk fed calves during pre weaning from birth to 4 weeks of age. Susceptibility to diarrhea is likely due in part to problems in management, such as inadequate cleanliness, and ventilation. Jasper and Weary (2002) explained that variation in immune functioning will also affect susceptibility, and this functioning in dairy calves is compromised under low levels of nutrition (Pollack et al., 1993). Indeed, recent work has shown that increased feeding of milk can go some way to improving calf immunity and performance (Nonnecke et al., 2000).

\section{CONCLUSIONS}

A polynomial trend in daily milk intake (as percent of body weight) was observed in calves fed ad libitum with maximum milk intake (23.15\% of body weight) between 4 to 5 weeks of their age. Ad libitum fed calves consumed 2.28 times higher daily milk intake than conventional fed calves. however, they consumed less solid feed. Calves fed more milk remained healthy and gained higher weight before weaning and maintained this advantage for at least up to $90 \mathrm{~d}$ of their age. However, we suggest more investigations are needed to develop an alternative calf milk feeding system to reduce stress, poor growth and health associated with restricted milk feeding and delayed solid feed consumption with ad libitum milk supply. Thus further research is warranted to investigate a hypothesis that the reduction in the quantity of milk offered to calves after d 30 of age (step-down) would result in increased solid feed consumption and improved body weight gain during the prep-weaning and post-weaning periods.

\section{ABSTRACT}

This study was conducted to estimate the maximum amount and time of milk consumption by Holstein calves during two months of preweaning period and to compare ad libitum milk feeding with conventional system for their effects on dry feed consumption, nutrient intake, growth performance and occurrence of diarrhea during the pre-weaning phase. Holstein calves $(n=20)$ 
were alternatively fed colostrum at $10 \%$ of their body weight or ad libitum for the first three days (d) and then assigned either to conventional $(n=10$; calves were fed milk at $10 \%$ of their body weight from birth to weaning at d 60 of their age) or ad libitum milk feeding $(\mathrm{n}=10$; calves were fed ad libitum milk from birth to weaning at d 60 of their age). Milk intake as a percent of body weight was increased in ad libitum fed calves from $13.59 \%$ at d 1 to $23.50 \%$ at $\mathrm{d} 30$ of their age, thereafter it was gradually reduced. Ad libitum fed calves consumed daily $9.8 \mathrm{~kg}$ milk compared with $4.3 \mathrm{~kg}$ milk in restricted fed calves $(p<0.05)$. Daily starter and mixed grass hay intake was gradually increased in both groups with the age however; the group differences were noted non-significant up to $40 \mathrm{~d}$ of age. Overall from birth to weaning conventionally fed calves ate 18.4, 20 and 18.9\% more dry matter, crude protein and total digestible nutrients, respectively than ad libitum milk fed calves $(p<0.05)$. Weight gain was 49, 18.4 and 26\% higher in ad libitum milk fed calves than conventionally fed calves during the first month, the second month and from birth to weaning, respectively $(p<0.05)$. Body weight was not significantly different between groups for the first $20 \mathrm{~d}$ of age. However, it was significantly higher for ad libitum milk fed calves at d 30, 40, 50, 60 (weaning) and 90 (post weaning) of their age $(\mathrm{p}<0.05)$. Similar body weights for both conventionally and ad libitum milk fed calves were observed for the post weaning period at 120,150 and $180 \mathrm{~d}$ of age. Feed efficiency was significantly higher for conventionally fed calves than ad libitum milk fed calves $(p<0.05)$. No sign of diarrhea, fever or cough was observed in calves fed either conventionally or ad libitum milk during the experimental period. In conclusion, calves fed more milk remained healthy and gained higher weight before weaning and maintained this advantage at least up to $90 \mathrm{~d}$ of their age.

\section{REFERENCES}

1. Albright, L. L. and Arave, C. W. 1997. The Behaviour of Cattle. CAB International, Wallingford, UK.

2. AOAC. 1999. Official Methods of Analysis, $16^{\text {th }}$ Ed. Association of Official Analytical Chemists, Washington, DC, USA.

3. Appleby, M. C., Weary, D. M. and Chua, B. 2001. Performance and feeding behaviour of calves on ad libitum milk from artificial teats. Appl. Anim. Behav. Sci. 74:191-201.

4. Bøe, K. and Havrevoll, Ø. 1993. Cold housing and computer-controlled milk feeding for dairy calves: behaviour and performance. Anim. Prod. 57:183-191.

5. Cady, R. A. and Smith, T. R. 1996. Economics of heifer raising programs. Proc. Calves Heifers and Dairy Profitability Nat. Con., Harrisburg, PA. NRAES Publ. 74, Ithaca, NY.

6. de Passillé, A. M. B., Metz, J. H. M. and Wiepkema, P. R. 1992. Does drinking milk stimulate sucking in young calves? Appl. Anim. Behav. Sci. 34:23-36.

7. Fiems, L. O., Boucqué, Ch. V., Cottyn, B. G. and Buysse, F. X. 1982. Effect of feeding techniques and age at weaning on the performances of bucket-fed and suckling reared calves. In: Signoret, J.P. (Ed.), Welfare and Husbandry of Calves, Current Topics in Veterinary Medicine and Animal Science. 19:149-167.

8. Flower, F. and Weary, D. M. 2001. Effects of early separation on the dairy cow and calf: 2 . Separation at 1 day and 2 weeks after birth. Appl. Anim. Behav. Sci. 70:275-284.

9. Hammell, K. L., Metz, J. H. M. and Mekking, P. 1988. Sucking behaviour of dairy calves fed milk ad libitum by bucket or teat. Appl. Anim. Behav. Sci. 20:275-285.

10. Hammon, H. M., Schiessler, G., Nussbaum, A. and Blum, J. W. 2002. Feed intake patterns, growth performance, and metabolic and endocrine 
traits in calves fed unlimited amounts of colostrum and milk by automate, starting in the neonatal period. J. Dairy Sci. 85:3352-3362.

11. Jasper, J. and Weary, D. M. 2002. Effects of ad libitum milk intake on dairy calves. J. Dairy Sci. 85:3054-3058.

12. Khalili, H., Crosse, S. and Varvikko, T. 1992. The performance of crossbred dairy calves given different levels of whole milk and weaned at different ages. Anim. Prod. 54:191-195.

13. Larson, L. L., Owen,, F. G., Albright, J. L., Appleman, R. D., Lamb, R. C. and Muller, L. D. 1977. Guidelines toward more uniformity in measuring and reporting calf experimental data. J. Dairy Sci. 60:989-991.

14. Leaver, J. D. and Yarrow, N. H. 1972. Rearing of dairy cattle. 2. Weaning calves according to their concentrate intake. Anim. Prod. 14:161-165.

15. Metz, J. 1987. Productivity aspects of keeping dairy cow and calf together in the post-partum period. Livest. Prod. Sci. 16:385-394.

16. National Research Council. 2001. Nutrient Requirements of Dairy Cattle. 7th rev. ed. Natl. Acad. Sci., Washington, DC.

17. Nocek, J. E. and Braund, D. G. 1986. Performance, health and postweaning growth on calves fed cold, acidified milk replacer ad libitum. J. Dairy Sci. 69:1871-1883.
18. Riordan, T. F. and Everitt, G. C. 1972. Effects of pre-weaning nutrition on subsequent growth rate, feed conversion efficiency and carcass composition of identical twin steers. Proc. N.Z. Soc. Anim. Prod. 32:26-38.

19. Rushen, J. and de Passillé, A. M. 1995. The motivation of nonnutritive sucking in calves, Bos taurus. Anim. Behav. 49:1503-1510.

20. SAS User's Guide: Statistics, Version 6.11 Edition. 1994. SAS Inst., Inc., Cary, NC.

21. Sjersen, K., Purup, S., Vestergaard, M. and Foldager, J. 2000. High body weight gain and reduced bovine mammary growth: physiological basis and implications for milk yield. Domest. Anim. Endocrinol. 19:93-104.

22. Thickett, W. S., Cuthbert, N. H., Brigstocke, T. D. A., Lindeman, M. A. and Wilson, P. N. 1983. A note on the performance and management of calves reared on cold acidified milk replacer ad libitum. Anim. Prod. 36:147-150.

23. Van Soest, P. J., Robertson, H. B. and Lewis, B. A. 1991. Methods of dietary fiber, NDF and nonstarch polysaccharides in relation to animal material. J. Dairy Sci. 74:3583-3597.

(접수일자 : 2006. 9. 25. / 채택일자 : 2006. 12. 12.) 